\title{
AWARENESS AND USE OF EMERGENCY CONTRACEPTION BY STUDENTS OF FEDERAL UNIVERSITY OF TECHNOLOGY, OWERRI
}

B. U. EZEM

(Received 4 March, 2008; Revision Accepted 7 August, 2008)

\begin{abstract}
Questionnaires were distributed to 335 randomly selected female students of Federal University of Technology Owerri in order to determine the awareness, knowledge and sources of information on emergency contraception. It was found that $29.5 \%$ of the respondents had had an induced abortion while $74.6 \%$ had used family planning .The percentage that correctly identified postinor, oral contraceptive and intra uterine contraceptive as methods of emergency contraception was 9;15.7; and $4.3 \%$ respectively. Only $16.5 \%$ knew the correct timing of emergency contraception and the main sources of information were doctors $(19 \%)$ and pharmacists $(15.8 \%)$ The potential benefits of emergency contraception remain largely untapped .It is suggested that all fresh students should be given talks on family planning as part of their orientation .
\end{abstract}

KEYWORDS: emergency contraception, awareness, knowledge, university students.

\section{INTRODUCTION}

Maternal mortality remains very high in developing countries with a national average of about 800 per 100,000 live births in Nigeria (Okonofua, 2004). One of the main causes of maternal mortality is abortion which in some developing countries accounts for about $21 \%$ of all maternal deaths (Mirembe,1996). Most of the deaths due to abortions are seen in youths and could have been avoided had the pregnancies been prevented in the first place by adequate contraception. Most youths although sexually active, have not established relationships which they consider stable enough to justify the use of the more reliable methods of contraception. In many, sexual relationships are multiple, unplanned, and often occurring on the spur of the moment (Araoye and Fakeye 1998).

Existing family planning clinics do not meet the needs of adolescents and are rarely patronized by adolescents because of the hostile attitude of these health workers. This scenario creates a situation in which emergency contraception would be the ideal option for these adolescents. The aim of this study is to find out the level of awareness, use, knowledge and sources of information about emergency contraception by these adolescents .

\section{METHOD}

The study was carried out between January and March 2007 in Federal University of Technology Owerri, in the South East of Nigeria. The total population of female students was 1400 and the minimum sample of respondents required was calculated to be 302 (Krejcie and Morgan,1970) .Three hundred and fifty female students were randomly selected from a list of all the female students. These students were then approached and requested to complete the

B. U. Ezem, Dept. of Obs and Gynae, Imo State University of Technology, P.M.B 08, Orlu, Nigeria. 
questionnaires. They were satisfactorily and anonymously completed by three hundred and thirty five students. The rest were unsatisfactorily completed and thus not suitable for inclusion. Each questionnaire contained fifteen questions. The first few dealt with demographic details while the others asked about previous abortion, sexual habits and the use of family planning .Other questions included previous knowledge of emergency contraception, agents used for it, effectiveness, timing, and sources of information about it.

\section{RESULTS}

Most of the respondents 174 (51.9\%) were between the ages of 20 and 24 (Table 1) with a mean age of $24.4+2.7$ yers. Two hundred and sixty six (81.3\%) respondents had never been married. A positive history of previous abortion was elicited in 97 (29.5\%) of respondents while $138(41.8 \%)$ had had sex in the four weeks predating their interview. The number of respondents who gave a history of previous use of family planning was $250(74.6 \%)$.

Table 1: Distribution of female students by selected characteristics.

\begin{tabular}{lcc}
\hline $\begin{array}{l}\text { Characteristic } \\
\text { Age }\end{array}$ & No & $\%(\mathrm{~N}=335)$ \\
$15-19$ & 26 & 7.8 \\
$20-24$ & 174 & 51.9 \\
$25-29$ & 87 & 26.0 \\
$>\quad 30$ & 48 & 14.3 \\
Marital Status $\quad(\mathrm{N}=327)$ & & \\
$\quad$ Single & 266 & 81.3 \\
$\quad$ Married & 48 & 14.7 \\
$\quad$ Divorced & 13 & 4.0 \\
Previous Abortions (N=329) & & \\
Yes & 97 & 29.5 \\
$\quad$ No & 232 & 70.5 \\
Sex in the last four weeks (N=330) & \\
Yes & 138 & 41.8 \\
No & 192 & 58.2 \\
Knowledge of emergency contraception & \\
Yes & 158 & 47.2 \\
No & 177 & 52.8 \\
Previous use of family planning & \\
Yes & 250 & 74.6 \\
No & 85 & 25.4 \\
\hline
\end{tabular}

Among this group (Table 11) the most popular methods were condom $88(34.9 \%)$, safe period in $69(27.4 \%)$ and 'injections' in $43(17.1 \%)$ of cases. Of the $158(47.2 \%)$ who were aware of emergency contraception before the study $15(9 \%), 26(15.7 \%)$ and 7
$(4.2 \%)$ correctly identified postinor (a progesterone only pill), oral contraceptives and intra uterine contraceptive device respectively as agents which could be used for emergency contraception. 
Table 11: Methods of family Planning ever used

$\begin{array}{lcc}\text { Method } & \text { No } & \%(\mathrm{~N}=252) \\ \text { Condom } & 88 & 34.9 \\ \text { Withdrawal } & 16 & 6.3 \\ \text { Oral contraceptives } & 18 & 7.1 \\ \text { IUCD } & 10 & 4.0 \\ \text { Spermicide } & 8 & 3.2 \\ \text { Injections* } & 43 & 17.1 \\ \text { Safe period } & 69 & 27.4\end{array}$

* Injections (menstrogen, gynaecosid, ergometrine, quinine, cumorit)

Knowledge of methods of Emergency contraception

\begin{tabular}{lcc} 
Method & No & $\%(\mathrm{~N}=166)$ \\
Postinor & 15 & 9 \\
Oral contraceptives & 26 & 15.7 \\
IUCD & 7 & 4.2 \\
Gynaecosid * & 8 & 4.8 \\
Quinine * & 12 & 7.2 \\
Menstrogen * & 14 & 8.4 \\
Ergometrine * & 4 & 2.4 \\
Antibiotics * & 20 & 12.1 \\
Not sure & 60 & 36.2 \\
\multicolumn{1}{r}{ *Not an emergency contraceptive agent }
\end{tabular}

Table 111 shows that only 26 (16.5\%) knew the correct timing of emergency contraception tablets. Most respondents 60 $(39.2 \%)$ obtained their information about emergency contraception from doctors, 62 $(39.2 \%)$, pharmacists $30,(19 \%)$ and 25
$(15.8 \%)$ from nurses. One hundred and seventy respondents $(52.2 \%)$ would prefer emergency contraceptives to be widely and easily accessible while the rest thought otherwise. 
Table 111 : Response to questions among students who had knowledge of emergency contraception. $\mathrm{N}=158$

When can emergency contraception effectively to prevent pregnancy

$\begin{array}{lcc} & \text { No } & \% \\ \text { Within } 72 \text { hrs after sex } & 26 & 16.5 \\ \text { Till next period } & 24 & 15.2 \\ \text { Within one week } & 12 & 7.6 \\ \text { Don't know } & 50 & 31.6 \\ \text { Within } 24 \text { hrs } & 46 & 29.1\end{array}$

Source of information about emergency contraception

Doctors

Pharmacists

Nurses

Patent Medicine Dealers

Friends

Books and magazines

\section{DISCUSSION}

This study reveals a high level of sexual activity, previous abortion rate, poor knowledge $o$ and use of ineffective methods of contraception among students.

The possible limitation of the study is the tendency of respondents to under-report events like previous abortions which are negatively perceived .

The sexually active proportion $(41.8 \%)$ in this study is less than that of $56.1 \%$ from Lagos (Obuebi, et al 2006) . This may be due to the highly cosmopolitan nature of Lagos.
62

39.2

30

19.0

25

15.8

17

10.8

15

9.5

9

5.7
Similarly while $250(74.6 \%)$ had previously used family planning in this study nearly all $96.8 \%$ had practiced family planning in the study from Lagos (Obuebi, et al 2006). This again is not unexpected for the reason adduced above.

The level of previous abortion of $29.5 \%$ is similar to the $34.4 \%$ recorded in Benin (Aziken,et al 2003). Rather appalling is the very poor level of accurate knowledge not only of the methods used for emergency contraception but of the correct timing of such intervention. In this study only $48(14.3 \%)$ respondents correctly identified 
oral contraceptive pill, postinor and intra uterine contraceptive device as methods of emergency contraception. On the other hand nearly double that percentage (26.5\%) correctly identified the same substances in the study from Benin (Aziken, et al 2003) .This difference in knowledge is difficult to explain given the fact that the two cities have similar abortion rates and at par with regards to urbanization.. Very few respondents $(16.5 \%)$, knew the correct timing of the administration of emergency contraception tablets in this study while a much higher percentage $(58 \%)$ got the timing right in Uganda (Bimugisha, et al 2006).A similar result was obtained in a study of hospital workers (Efetie, et al 2002). While friends were the major source of information in some studies (Bimugisha, et al 2006, lkeme, et al,2005,Aneblom, et al 2002) doctors were the major source of information in this study. The media which were the main source of information in a study from Ghana (Baiden, et al,2002) did not feature prominently in this study.

The very poor level of awareness of emergency contraception and an even poorer knowledge of the correct timing of it's administration results in the near complete wastage of the huge potential benefits of emergency contraception particularly in this high risk group. To address this issue it is suggested that fresh university students should be given talks on family planning particularly emergency contraception during their orientation. The fear that this will lead to increased sexual activity is unsubstantiated. Doctors in university medical centers should also be properly informed as one study (Ebuehi,et al 2006) showed that only 35\% of physicians had good knowledge of emergency contraception.

The potential of the mass media in disseminating information which has been demonstrated in Ghana (Baiden, et al 2006) could be replicated in other developing countries. This is important because women must first know that it exists before they can make use of it (Haggai , 2003).

\section{REFERENCES}

Aneblom ,G.,Larsson ,M., Odlina V., Tyden T., 2002. Knowledge and attitudes towards emergency contraception pills among Swedish women presenting for induced abortion. Brit J Obs Gynae 109(2):155-60.

Aziken, M. E., Okonta, P. I., Ande , A.B.A., 2003. Knowledge and perception of emergency contraception among female undergraduates. Int. Fam. Plann perspect.29 (2):84-87.

Baiden, F., Awini, E., Clerk, C., 2002. Perceptions of university students in Ghana about emergency contraception. Contraception 66 (1):13-16.

Biamugisha, J. K.,Mirembe, F. M., Faxelid E, Gemzell-Danielsson,K.,.Afri Health Sci 6( 4): 194-200.

Ebuehi, O,.M, Ebuehi, O. A. T., Inem, V., 2006. Healthcare providers knowledge of, attitudes toward the provision of emergency contraceptives in Lagos, Nigeria .Int Fam Plann Perspect 32 (20):89-93.

Efetie, E. R., Umezulike, A., Agboghoroma, C.O.,Ewuzie-Wokocha,M.A.,2002, Nig J Clin Pract. 5 (2):99-102.

Haggai, D., 2003. Emergency contraception: A global overview of knowledge attitudes and practices among providers. Trop. J Obs. Gynaec 20:153-158

Ikeme, A. C., Ezegwu, H. U.,Uzodinma, A.C., 2005. Use of emergency contraception among female undergraduates in Eastern Nigeria. J Obs Gynec 25(5):491-493. 
Krejcie, R. V., Morgan, D. W.,1970. Determining sample size for research activities.Educ Psychol Meas. 30(4): 607-610.

Mirembe, F. M.,1996.A situation analysis of induced abortion in Uganda. Afr. J Fertil Sex Reprod Health.1 (1):79-80.
Obuehi, O. M.,Ekanem, E.E.,Ebuehi, O.A.T., 2006. Knowledge and practice of emergency contraception among female undergraduates in University of Lagos, Nigeria. East Afri Med J. 83(3):90-95.

Okonofua ,F., 2004. Maternal mortality in Nigeria: a call to action. J Biom Res.3(2): 4-6. 